(1)

\title{
ENABLERS FOR ALLIED HEALTH FRONT-LINE MANAGERS IN PUBLIC HEALTH ENVIRONMENTS TO DELIVER SUSTAINABLE PATIENT CARE
}

\author{
Gemma Turato', Florin Oprescu² \\ 1. Executive Director Allied Health, Sunshine Coast Hospital and Health Service, Sunshine Coast, Queensland, Australia \\ 2. Senior Lecturer, University Sunshine Coast, Queensland, Australia
}

Correspondence: gemma.turato@health.qld.gov.au

\section{ABSTRACT}

\section{BACKGROUND:}

Many allied health managers do not feel equipped to face the challenges of evolving business environments such as public hospitals The increasing demand on public hospitals due to chronicity of disease, an aging population and rising health costs will require managers to be resourceful, adaptable, influential and innovative The research on this topic is scarce with a lack of robust studies specific to allied health front-line managers working in public healthcare settings.

\section{OBJECTIVES:}

The review of the literature aims to identify enablers for front-line allied health managers to be more effective and better prepared for working in complex and challenging healthcare environments such as public hospitals.

\section{METHOD:}

Literature searches were performed using Scopus, PubMed, PsychINFO, CINAHL, Proquest and Google Scholar databases for articles published between January 2000 and November 2019. Hand searching of reference lists of included papers also occurred. The included articles were studies containing cohorts of allied health professionals working in any healthcare setting that directly related to the study of management and/or leadership.

\section{RESULTS:}

The literature findings on this topic was scarce, however review of the 22 studies that met the criteria identified nine potential enablers for allied health front-line managers. These included incorporating effective leadership styles, leadership attributes and characteristics for working in health, allied health structure, representation of allied health in contexts of influence, associations / network and organisational support, evidence based and tailored allied health programs, measurable and robust feedback on performance and succession planning for the future.

\section{CONCLUSION:}

By identifying potential enablers, key strategies, resources and supports could be developed for allied health frontline managers working in complex settings such as public hospitals, that ultimately lead to improvements in patient safety, quality and experience.

\section{IMPLICATIONS FOR PRACTICE:}

More research with front-line allied health managers in practice is required to explore and validate the identified enablers. Once validated, further studies to determine the strategies, resources, influences and supports that could be developed to support enacting them would be important. Providing the necessary enablers to allied health front-line managers would equip them to manage the increasing challenges facing public healthcare organisations that are required to be more sustainable while delivering quality care to patients. 


\section{KEYWORDS}

Management, Allied Health, Leadership, Enablers, Public Sector Healthcare

\section{INTRODUCTION}

Many allied health managers do not feel equipped to face the challenges of evolving business environments such as public hospitals. [1-6] The increasing demand on public hospitals due to chronicity of disease, an ageing population and rising health costs will require managers to be resourceful, adaptable, influential and innovative. $[1,3,6-9]$ The research on this topic is scarce with a lack of robust studies specific to allied health front-line managers working in public healthcare settings. [1]

A succinct definition of allied health is difficult to articulate. The Allied Health Professions Australia (AHPA) describes these sub-set of professionals as autonomous practitioners that practice in an evidence-based paradigm with expertise in preventing, diagnosing and treating a range of conditions and illnesses and generally have a university qualification. [10] Allied health encompasses a diverse range of health professionals typically including: audiology, dietetics, diversional therapy, exercise physiology, music therapy, occupational therapy, orthoptics, pharmacy, physiotherapy, podiatry, psychology, radiographers, social work and speech pathology. $[10,11]$

There is increasing attention amongst policy makers, healthcare administrators, healthcare workers and researchers around the world regarding the sustainability of the health care industry into the future. $[8,9,12]$ This is being driven by an ageing population, expensive medical interventions, community expectations and the rise in the incidence of chronic conditions. [1,3,7-9,13] Managers primary function is to get people to work together to fulfil an organisation's goals and objectives, focusing on organisation, direction and control of work to ensure a level of quality. [14] However, managers are being confronted by significant issues such as rising health costs, a projected reduction in healthcare workforce and equitable access to healthcare for disadvantaged groups. The constant focus of doing more with less could impact management's ability to deliver good quality healthcare to patients in the future. $[9,13]$
The limited research reviewed indicates that allied health managers working in increasingly complex and challenging healthcare environments such as public hospitals do not feel equipped to manage the issues they are facing. [1-7,9] Nevertheless, allied health professionals have a multitude of skills, knowledge and expertise that could be utilised to assist public health organisations tackle current and future issues in an efficient and cost-effective manner. [2,9] The challenge for allied health front-line managers is having the necessary skills, resources and influences to support staff to endure working in these highly pressured environments that require employees to be adaptable, flexible and resilient, often with minimal provision. [4]

The literature review presented addresses the following question: "what are the enablers for front-line allied health managers to deliver sustainable and safe patient care in complex and challenging healthcare environments like public hospitals?"

\section{METHODS}

An electronic Title/Abstract/Keyword search of relevant published literature was performed utilising Scopus, PubMed, PsychINFO, CINAHL, ProQuest and Google Scholar databases. Search terms included 'allied health management', 'managers', 'allied health leadership', 'leaders', 'allied health occupations' AND 'health care' AND 'programs.' Due to scarcity of the literature the search was expanded to include specific professions as defined by the AHPA [10], as well as international literature from contexts similar to Australia. The search was performed in December 2018 with an updated search performed in November 2019.

The electronic search yielded 85 references, an additional 5 were identified via reference searching. A total of 22 research studies with cohorts of allied health participants met the inclusion criteria outlined in Table 1. The selection process and criteria are shown as a Prisma diagram in Figure 1. A summary of the published research studies, including: aims, setting, design, characteristics and study findings can be found in Table 3 . 
TABLE 1: INCLUSION / EXCLUSION CRITERIA

\begin{tabular}{|l|l|}
\hline \multicolumn{1}{|c|}{ INCLUSION CRITERIA } & \multicolumn{1}{|c|}{ EXCLUSION CRITERIA } \\
\hline Allied health participants as defined by AHPA & Irrelevant setting i.e. non health related \\
\hline $\begin{array}{l}\text { All environments / settings - public, private, } \\
\text { associations }\end{array}$ & Literature reviews \\
\hline $\begin{array}{l}\text { Management / leadership terms identified in } \\
\text { the article }\end{array}$ & Non-allied health cohorts of participants \\
\hline $\begin{array}{l}\text { Research study with cohorts of allied health } \\
\text { Participants or a single profession e.g. } \\
\text { Occupational Therapy, Physiotherapy, Social } \\
\text { Work, Pharmacy }\end{array}$ & Irrelevant topics e.g. supervision \\
\hline $\begin{array}{l}\text { Articles published between 2000-2019 } \\
\text { similar context }\end{array}$ & Conference / forum presentations, reports \\
\hline
\end{tabular}

Each article was reviewed by the principle researcher and the data summarised. The analysis of the articles was guided and reviewed by a second researcher to ensure nothing was overlooked or misinterpreted. The word 'enablers' was defined for this review as: "capabilities, forces and resources that contribute to the success of an entity, program or project". [15] The principle researcher identified capabilities, forces and resources described in the studies and summarised these into themes to determine a final list of enablers for discussion (Table 2).

\section{TABLE 2: ENABLERS FOR ALLIED HEALTH MANAGERS}

\begin{tabular}{|l|l|}
\hline ENABLERS & \multicolumn{1}{|c|}{$\begin{array}{c}\text { RELEVAT } \\
\text { LITERTRE }\end{array}$} \\
\hline Incorporating effective leadership styles & $2,3,7,12,16-24$ \\
\hline Management/leadership attributes and skills for working in health & $1,4-6,8,14,16,25-30$ \\
\hline Viable allied health structure & $1,2,9,29$ \\
\hline Representation of allied health in contexts of influence & $1,2,9,29,31$ \\
\hline Associations and network support & $2,10,32$ \\
\hline Organisational support for front-line managers & $1,2,4,5,9,16,18,28$ \\
\hline Evidence based and tailored allied health management / leadership training & $1,2,7,29,31-35$ \\
\hline Measurable and robust feedback on performance & 7,35 \\
\hline Ensuring allied health succession planning occurs at all levels & $13,36,37$ \\
\hline
\end{tabular}




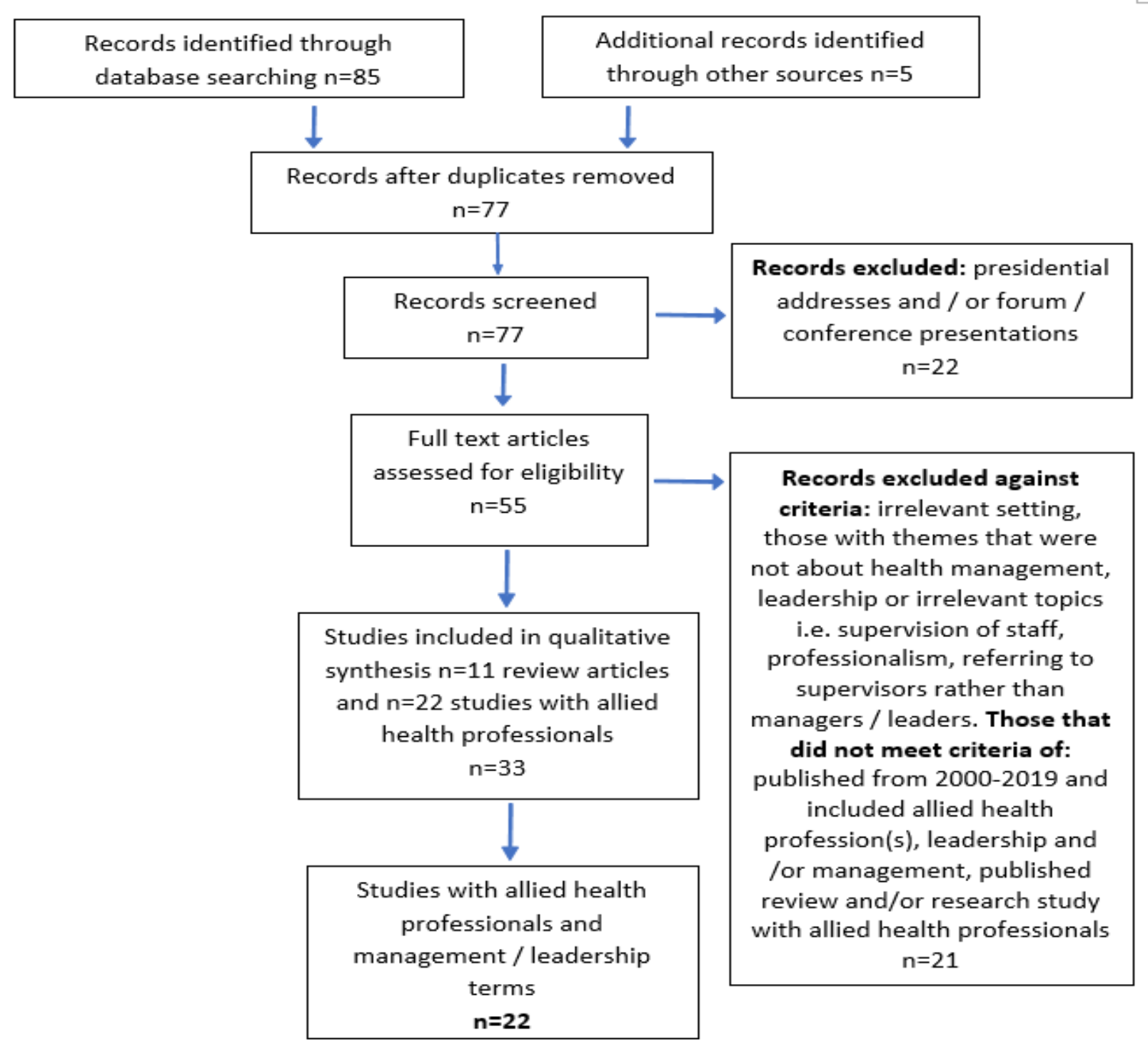

\section{RESULTS}

The enablers for allied health front-line managers to deliver safe and quality outcomes for patients accessing healthcare organisations will be described in turn.

\section{INCORPORATING EFFECTIVE LEADERSHIP STYLES}

Research suggests that effective leadership styles are directly associated with leadership outcomes [3,16-18] and that different types of leaders are required for different situations. [3,7,12,19-21] Despite conflicting views in the literature, many supported the viewpoint that both sound management (utilise more of the transactional style where managers reward or discipline staff to achieve outcomes) and strong leadership (utilise more of the transformational style) are essential to the longer-term viability of today's public health organisations, which face substantive change. [3,7,12,19-23]

Furthermore, the most frequently observed leadership style in high performing managers incorporates those components outlined in transformational leadership. $[2,3,7,12,17,20,23]$ This type of leadership motivates employee performance through role modelling behaviour that followers want to emulate, they build trust and encourage and inspire those around them as well as stimulate followers to bring forth new ideas and be innovative. They act as a coach, mentor, teacher, facilitator, confidant, and counsellor which provides support and reassurance to their followers. [17,20,22-23]

A study of physiotherapists in Ireland supported the enabler of developing an effective style of leadership and stated that the current shortened version of the multifactorial leadership questionnaire (MLQ) named the MLQ $5 X$ is a valid and reliable instrument that can adequately measure 
leadership styles. [7] They concluded it could assist with the foundation for understanding some of the critical components required in relation to adopting effective leadership styles.

Although there has been significant research on transformational leadership, other scholars are suggesting that transformational and transactional leadership may not adequately capture all the leadership behaviours relevant for organisations. [22,24] Other behaviours beyond these styles of leadership were required for organisations to be successful. Examples include pragmatic dimension, community orientation from servant leadership and aspects of ethical leadership to further enhance transformational leadership. [24]

\section{MANAGEMENT / LEADERSHIP ATTRIBUTES AND SKILLS FOR WORKING IN HEALTH}

Similar to incorporating effective leadership styles, developing appropriate attributes in managers can produce more effective outcomes within high pressured healthcare environments. [4] Managers who use a caring approach, such as supporting, encouraging, negotiating, respecting, accepting and trusting, may be able to provide improved staff support, more satisfying work conditions and retain staff for longer than "boss" managers. Boss managers often use a more negative approach such as blaming, criticising, complaining, rewarding to control, threatening, punishing and nagging behaviours. [4]

An Australian study interviewed directors of allied health in New South Wales (NSW) who described the attributes of successful allied health leaders as strong communication and listening skills, the ability to set a clear vision or direction, being innovative, showing authenticity, integrity and being accountable. [1] Other studies reviewed identified good communication, credibility and professionalism as key attributes for managers in healthcare. $[5,6,8,14,16,25,27]$

Further studies identified leadership characteristics and skills which are consistently associated with effective leadership in multiple health fields: emotional intelligence, vision and business acumen. [6-8,25-30] A study of physiotherapy leaders further supported these findings, with business skills perceived as very important within health organisations for starting or expanding a new service or facility within a hospital department. [5,30]

\section{VIABLE ALLIED HEALTH STRUCTURE}

In Australia there has been variation in allied health structures proposed and trialed in many hospitals across rural, regional and tertiary levels over the past few decades, with anecdotal feedback on the dire consequences of inappropriate structures from a few public hospitals in Queensland. [1,9,29] The division of allied health or integrated decentralisation approaches have proven to be viable models for structuring allied health and are continuing to grow in number as more research and evidence is published about their success. $[2,9,29]$

Findings from a recent study of allied health structures and leadership in the state of Queensland supports these findings, concluding that management of the allied health workforce is more effective with an integrated operational and professional governance structure with single points of accountability overseeing professional groups. [9] However, successful implementation and operation of this structure required credible, skilled and respected allied health mangers to enact them. [8,9]

\section{REPRESENTATION OF ALLIED HEALTH IN CONTEXTS OF INFLUENCE}

An issue facing allied health appears to be poor representation within leadership positions that can influence change within healthcare systems. [1,2,9,29] The study of allied health directors in NSW reported many participants felt powerless to affect the healthcare system compared with clinical colleagues. [1] They stated that although there is evidence that allied health professionals are well positioned to lead health system change, they remain under-represented in senior decision-making roles. [1]

Similarly, in a study of top management teams and boards in Australia, findings demonstrated allied health has small numbers in both; significantly lower than medicine and nursing. [29] They reported there was a fragmentation of services within the health care industry that lacked a defined point of accountability for allied health managers to drive change and quality standards. [29] Another Australian study stated that despite the numbers of allied health working in the healthcare industry, the contribution and value of allied health practitioners to improved health outcomes, remains under-represented in health policy, leadership and organisational reform settings. [2]

An international study undertook ethnographic fieldwork at four healthcare sites in England concluding that allied 
health managers could contribute significantly to the National Health Service (NHS) in England if fully utilised. However, they found that a traditional model of leadership existed, consisting of exceptional, heroic individuals occupying positions of formal authority. They concluded this was against the distributed style of leadership being promoted as an effective type of leadership for healthcare today. [31]

A Queensland study interviewed five executives and 49 allied health professionals across nine health services and found that Executive allied health positions enabled allied health leaders to use their influence in organisational planning and decision-making to deliver effective patient care services. [9]

\section{ASSOCIATIONS AND NETWORK SUPPORT}

A 2016 Australian report recommended that to progress allied health leadership development, collaborations with many sectors, including professional bodies is crucial to ensure all facets of the health context are considered in the development of system wide leaders. [2] No further literature or published reports indicate if progress has been made with this recommendation at a national level in Australia, however the AHPA has an online network for allied health leaders who wish to linkup with other leaders across Australia. The aim is for leaders to pursue interprofessional collaboration and sharing of information relevant to allied health teamwork in service delivery, research and education. [10]

An example of leadership support that was developed by the Association of Schools of Allied Health Professions which was chartered in Washington, D.C in September 1967 is a not-for-profit national professional association for administrators, educators, and others who are concerned with critical issues affecting allied health education and practice. They recommended that there should be a national effort to prepare emerging leaders in allied health education and practice, which resulted in the association setting up a coalition of allied health leadership which is still active. [32]

\section{ORGANISATIONAL SUPPORT FOR MANAGERS}

Health organisations can be difficult places for front-line allied health managers to work due to minimal training and resources being in place to support managers. $[1,2,16,28]$ Available research indicates that leadership capability impacts organisational performance and outcomes, making training on the matter an essential element of success for organisations. [1,2,5,18,28]

A Queensland study concluded that organisations providing clinical support, education, supervision, and the ability to engage in research can develop a sustainable, skilled and capable allied health workforce. [9] Furthermore, those organisations that provide effective and reliable data management systems allow allied health managers to design, implement and evaluate clinical service delivery. [9]

In a study of 138 allied health staff across public and private practice the researchers concluded that without clear expectations and support from the organisation on how teams should behave and work collaboratively to achieve the best outcomes, the issues described by allied health managers working in public health environments will continue. [4] They identified factors for allied health managers to support staff, recommending they provide a comprehensive orientation to the workplace and take the time to ensure staff understand the roles and responsibilities of their job description. [4]

\section{EVIDENCE BASED AND TAILORED ALLIED HEALTH MANAGEMENT / LEADERSHIP TRAINING}

The literature highlighted key points to consider in training allied health front-line managers. One study concluded that allied health clinicians have little preparation in business, regulatory policy, or financial matters and often feel inadequately trained to be competent in administrative roles. [29] Another study supported this finding, stating participants reported the transition from clinician to manager was complex due to the lack of skills in administration. [1]

A different factor included the variances in professions in relation to training needs. One international study exploring self-reported transformational leadership behaviour profiles found some allied health professional groups (radiographers and podiatrists) may require significantly more support than others due to their lower scores in the transformational leadership style. [7] Furthermore, directors of allied health described a different complexity of transitioning from a profession-specific manager to one being capable of encompassing the challenges and concerns of the wider professional groups. They stated that managing multiple professions and professionals and harmonising their organisational and professional efforts was challenging. [1,31] They recommended the 
development of a state-wide leadership training, mentoring and coaching program specifically for the directors of allied health. [1]

Other enablers mentioned in the literature were targeting emerging / early career leaders and students in leadership development opportunities to build leadership skills early or before allied health practitioners enter the work force. $[2,29]$ Another involved reviewing collaborative approaches between health, academic institutions, allied health, medical and nursing leadership bodies with strong governance to drive implementation. [1,2,29] The final suggestion involved developing evidence-based training models and/or frameworks tailored to individual needs to deliver effective outcomes. [1,2,29,31-35] A study within an Australian public health organisation demonstrated the effectiveness of using practice development methods for allied health leadership development. [33] The program received high ratings from participants, reporting enhanced skills in leading self and others, greater confidence in managing change and engaging with staff, colleagues, and patients. [33]

\section{MEASURABLE AND ROBUST FEEDBACK ON PERFORMANCE}

A study of transformational leadership behaviours in allied health professionals recommended implementing a robust evaluation program to measure the impact of leadership training, in terms of behavioural change and organisational outcomes. [7] This study found scope for utilising the MLQ in measuring specific allied health practitioner leadership behaviours before and after the delivery of leadership training. They recommended moving beyond impression management, with evaluation based on qualitative feedback, to a substantial evaluation which identifies specific areas of leadership training required by staff. [7]

A study on the preliminary validation of a leadership competency instrument for existing and emerging allied health professionals developed and tested a leadership competency instrument with 106 allied health professionals of varying levels. [35] They demonstrated initial evidence (internal consistency of $>0.88$ ) for the use of an instrument to assess leadership competency in allied health professionals. [35] No such instruments appear to exist that assess leadership competency in current and emerging allied health professionals, however, they stated being able to accurately assess leadership performance is vital in the development and improvement of health organisations. [35]

\section{ENSURING ALLIED HEALTH SUCCESSION PLANNING OCCURS AT ALL LEVELS}

One of the key factors in approaching the issues of ensuring competency in management and leadership in allied health is training that produces results and layers of succession planning that maintains momentum. There is a need for current allied health front-line mangers to future proof the development of emerging allied health managers through appropriate training, coaching and mentoring programs. [13]

In literature, a review by researchers concluded that a successful pharmacy department should have a developing succession plan that systematically reviews all employees to identify their strengths and areas to improve. They recommended organisations take a proactive stance in leadership succession planning, so they are better equipped to manage change. [36]

Further literature suggested utilising the annual performance review which is a mandatory requirement in all healthcare organisations. If utilised effectively this would be the time to begin the preparation process for succession planning and creating a culture of leadership. [37] In addition, the manager could assist the employee to prepare a plan that includes online courses, readings, attendance at relevant meetings, mentoring/coaching and the possibility for work shadowing opportunities. [37] Supplementary examples included participation in hospital committees, preparing for accreditation visits, or leading projects to learn, make contacts and gain on-the-job experience. [37]

\section{DISCUSSION}

The literature review of enablers for allied health front-line managers working in public health environments generated limited published evidence. However, the results from the studies reviewed identified nine potential enablers that could support allied health front-line managers to deliver safe and quality care to patients.

Of the enablers identified, five are within allied health frontline managers influence through seeking appropriate training, coaching and/or mentoring. The first two enablers included incorporating the right leadership styles and attributes $[3,7,12,19-24]$, including growth in business and administration skills. [5,6,8,25-27] The third and fourth enablers comprised of ensuring skills development is tailored to meet the needs of the manager and the context 
they are working in $[1,7,31,30]$ and obtaining measurable and robust feedback on performance. [7,35] The fifth included establishing a succession planning framework that supported staff at all levels to gain skills in management / leadership. [13,35-37] These five enablers could be initiated by the allied health front line manager as part of a tailored program incorporated into the annual performance appraisal and development planning process reviewed 6-monthly, including a robust evaluation tool to provide constructive feedback on performance.

A further four enablers would require authorisation from others to enact the forces and system changes required and many were reported in studies as barriers to progress for allied health. Therefore, these enablers may need a high-level collective approach from allied health influencers to support front-line managers to enact them. The first enabler has strong evidence that the division of allied health or integrated decentralisation approaches have proven to be viable models for allied health structures $[1,2,9,29]$ and should continue or be enacted when healthcare organisations decide to re-structure.

The second enabler has solid evidence to suggest allied health needs to raise its profile in contexts of influence, not only for the future of allied health, but for the sustainability of healthcare organisations. [1,2,9,29] A few articles suggested to raise the influence of allied health within local contexts would require developing a state or national strategy on key allied health issues. Additionally, the strategy should outline evidence-based recommendations that support allied health front-line managers to advocate for key enablers and / or influence change. [1,2,29] Executive allied health roles are positioned well to be strong influencers and lead the development of a collective strategy by collaborating with many sectors including education, professional associations, private and public healthcare organisations as well as working with nursing and medicine to build better partnerships. [1,2,9,29,31]

Furthermore, the third enabler of allied health associations and networks providing support for a collective strategy around matters / issues of significant importance for allied health at a state and national level could add significant momentum for change. [2,29] The fourth enabler of organisational support was included in several articles reviewed with data suggesting that organisations that provide appropriate training and resources for front-line managers are more successful and retain staff for longer. $[1,2,4-6,9,16,18,28,29,33]$
This paper summarises the potential enablers from the limited published information available. The data over the past two decades highlights many issues for allied health front-line managers working in healthcare organisations. Even with clear recommendations in the literature, it appears that little has changed for allied health managers working in these environments when compared with medicine and nursing. From a practical perspective, a focus on developing the professional identity of allied health in general and of allied health managers in particular is a worthy direction for the discipline [38].

The findings demonstrate the impact enablers could have on the ability of front-line managers to perform effectively in their role and may provide a framework for allied health to take up the challenge as a collective group in testing and enacting these enablers within healthcare organisations. A high-level collective approach by allied health at the state and national level could force the change required to be recognised in contexts of influence, alongside medicine and nursing. This is crucial for allied health as a workforce so they can contribute meaningfully on current and serious issues such as sustainability of the healthcare industry, to ensure safe and quality care is delivered to patients and consumers accessing healthcare.

\section{LIMITATIONS}

Many of the studies reviewed did not identify the context due to administering surveys through associations where participants worked in a variety of settings. It was felt that many of the enablers identified in any healthcare setting would be applicable to a public hospital environment and therefore were included for review.

\section{CONCLUSION}

Allied Health has a very important and unique role in health care. To be successful in today's fast-moving, changeresponsive healthcare organisations, there is a need for proficiently trained allied health managers who can navigate and respond appropriately to the complexities of the system. This proficiency could include the ability to analyse the political environment in which they work and to use that knowledge to effect positive change and to create enablers. Providing the necessary enablers to allied health front-line managers would equip them to manage the increasing challenges facing public healthcare organisations that are required to be more sustainable while delivering quality care to patients. From a theoretical 
perspective the paper provides a list of enablers that can be organised in a theoretical framework as part of future research. Identifying the enablers that might provide allied health managers with leadership skills to support change processes at all levels is essential. Future research should aim to further evaluate the enablers for allied health managers working in complex public health environments and determine why they may not be in place. This is vital, in order for allied health front-line managers to have the required capabilities, forces and resources to contribute fully to healthcare organisations. Furthermore, research about how allied health can build a collective strategy at a state and national level that influences healthcare policy and system change could assist organisations to be more sustainable, as well as support allied health front-line managers to have a stronger voice at the local level.

THE AUTHOR(S) DECLARE(S) that there is no conflict of interest.

ACKNOWLEDGEMENT: We would like to acknowledge those who reviewed this paper for their time and feedback

\section{References}

1. Bradd P, Travaglia J, Hayen A. Allied Health Leadership in New South Wales: a research program of perceptions and priorities of allied health leaders. Aust Health Rev 2017; 42(3):316-320. https://doi:10.1071/ah16135.

2. Joubert L, Boyce R, Mckinnon F, Posenelli S, MeKeever M. Strategies for allied health leadership development: enhancing quality, safety and productivity. Victoria: Department of Health and Human Services; 2016.

3. Snodgrass J, Douthitt S, Ellis R, Wade S, Plemons J. Occupational Therapy Practitioners perceptions of rehabilitation managers leadership styles and the outcomes of leadership. J. Allied Health 2008; 37(1):3844.

4. Stagnitti K, Schoo A, Dunbar J, Reid C. An Exploration of issues of Management and Intention to Stay: Allied Health Professionals in South West Victoria, Australia. J. Allied Health 2006; 35(4):226-232.

5. McGowan E, Stokes E. Leadership and leadership development within the profession of physiotherapy in Ireland. Physiother. Theory Pract. 2017; 33(1):62-71. https://doi:10.1080/09593985.2016.1230659.
6. McGowan E, Martin G, Stokes, E. Perceptions of Leadership: Comparing Canadian and Irish Physiotherapists' Views. Physiother Can 2016; 68(2):106113. https://doi:10.3138/ptc.2014-95.

7. Wylie D, Gallagher H. Transformational Leadership Behaviours in Allied Health Professions. J. Allied Health 2009; 38(2):65-73.

8. Desveaux L, Verrier M. Physical Therapists' Perceptions of Leadership across the Health Care Continuum: A Brief Report. Physiother Can 2014; 66(2):119-123. https://doi:10.3138/ptc.2013-02.

9. Mickan S, Dawber J, Hulcombe J. Realist evaluation of allied health management in Queensland: what works, in which contexts and why. Aust Health Rev 2018; 43:466-473.

https://doi.org/10.1071/AH000201.

10. Allied Health Professions Australia. Available: https://ahpa.com.au/about-ahpa> 2019; (Accessed 10/11/19)

11. Bradd P, Travaglia J, Hayen A. Leadership in Allied Health: A Review of the Literature. Asia Pac. J. Health Manag 2017; 12(1): 17-24. https://doi:10.24083/apjhm.v12i1.103.

12. MacKie D. The Effectiveness of Strength-based Executive Coaching in Enhancing Full Range Leadership Development: A Controlled Research program. Consult. Psychol. J.: Pract. Res. 2014; 66(2):1 18-137. https://doi.org/10.1037/cpb0000005.

13. Rodger S. Leadership through an occupational lens: Celebrating our territory. Aust. Occup. Ther. J. 2012; 59(3):172-179. https://doi:10.1111/j.14401630.2012.00995.x.

14. Fleming-Castaldy R, Patro J. Leadership in Occupational Therapy: Self Perceptions of Occupational Therapy Managers. Occup Ther Health Care 2012; 26(2-3):187-202.

http//doi:10.3109/07380577.2012.697256.

15. BusinessDictionary.com. Available: http//www.businessdictionary.com/definition/enablers .html (Accessed 25/11/19)

16. Kutz M. Leadership in athletic training: Implications for practice and education in allied health care. J. Allied Health, 2010; 39(4):265-279.

17. Gellis Z. Social Work Perceptions of Transformational and Transactional Leadership in Healthcare. Soc. Work Res. $2001 ; 25(1): 17-25$. 
18. Guerrero E, Padwa H, Fenwick K, Harris L, Aarons G. Identifying and ranking implicit leadership strategies to promote evidence-based practice implementation in addiction health services. Implement Sci 2015; 11 (69):3-13. http//doi:10.1186/s13012-016-0438-y.

19. Aarons G, Ehrhart M, Farahnak L, Hurlburt M. Leadership and organizational change for implementation (LOCI): a randomized mixed method pilot study of a leadership and organization development intervention for evidence-based practice implementation. Implement Sci 2015; 10(1 1):2-12. http//doi:10.1186/s13012-014-0192-y.

20. Avolio B. Full Range Leadership Development (Second Edition). Thousand Oaks, CA: Sage Publications; 2010.

21. MacLeod L. A Broader View of Nursing Leadership: Rethinking Manager-Leader Functions. Nurse Lead. 2012; 10(3):57-61.

22. Anderson M, Sun P. Reviewing Leadership Styles: Overlaps and the Need for a New 'Full-Range' Theory. Int. J. Manag Rev. 2017; 19:76-96. http//doi:10.1111/ijmr.12082.

23. Firestone D. A Research program of Leadership Behaviours among Chairpersons in Allied Health Programs. J. Allied Health 2010; 39(1):34-42.

24. Antonakis J, House R. Instrumental leadership: measurement and extension of transformationaltransactional leadership theory. Leadersh Q. 2014; $25: 746-771$.

25. Chan Z, Bruxer A, Lee J, Sims K, Wainwright M, Brooks $D$, Desveaux, L. What Makes a Leader: Identifying the Strengths of Canadian Physical Therapists. Physiother Can. 2015; 67(4):341-348.

26. Desveaux L, Chan Z, Brooks D. Leadership in Physical Therapy: Characteristics of Academics and Managers: A Brief Report. Physiother Can. 2016; 68(1):54-58. http//doi:10.3138/ptc.2011-42 doi:10.3138/ptc.2011-42.

27. Schafer D. Three perspectives on physical therapist managerial work. Phys. Ther. 2002; 82(3):228-236.

28. Hazelbaker C. Perceived Skills and Abilities Required by Athletic Trainers in Hospital and Clinical Management Positions: A Delphi Research program. J. of Athl. Train 2013; 48(1):87-91. http//doi:10.4085/10626050-47.6.2.

29. Boyce R, Jackway P. Allied Health Leaders: Australian Public-Sector Health Boards and Top Management Teams. Victorian Department of Health and Human
Services. Office of the Chief Allied Health Advisor; 2016.

30. Desveaux L, Nanavaty G, Ryan J, Howell P, Sunder R, Macdonald A, Verrier M. Exploring the Concept of Leadership from the Perspective of Physical Therapists in Canada. Physiother Can. 2012; 64(4):367-375. http//doi:10.3138/ptc.2011-42.

31. Petchey R, Hughes J, Pinder R, Needel, J, Partington J, Sims $D$. Allied health professionals and management: an ethnographic research program. National Institute for Health Research (NIHR), Service Delivery and Organisation programme. London: Queens Printer and Controller of HMSO; 2012.

32. Wilson S. Coalition of allied health leadership. J. Allied Health, 2004; 33(2):144.

33. Bradd P, Travaglia J, Hayen A. Developing allied health leaders to enhance person-centred healthcare. J Health Organ Manag 2018; 32(7):908932. http//doi:10.1071/ah16135.

34. McGowan E, Walsh C, Stokes E. Physiotherapy managers' perceptions of their leadership effectiveness: a multi-frame analysis. 2016; 103(3):289295. http//doi:10.3138/ptc.2014-95.

35. Ang H, Koh J, Lee, J, Pua, Y. Development and preliminary validation of a leadership competency instrument for existing and emerging allied health professional leaders. BMC Health Serv. Res. 2016; 16(64):1-8. http//doi:10.1186/s12913-016-1301-1.

36. Ellinger L, Trapskin P, Black R, Kotis D, Alexander E. Leadership and Effective Succession Planning in Health-System Pharmacy Departments. Hosp. Pharm. 2014; 49(4):369-375. http//doi:10.1310/hpj4904-369.

37. White S, Enright S. Is there still a pharmacy leadership crisis? A seven-year follow-up assessment. Am J. of Health Syst Pharm. 2013; 70(5):443-447. http//doi:10.2146/ajhpl20258.

38. Mak, Ka-Hi May, Louise Kippist, Terry Sloan, and Kathy Eljiz. "What is the professional identity of allied health managers?." Asia-Pacific Journal of Health Management 14, no. 1 (2019): 58-58. 


\section{TABLE 3: RESEARCH STUDIES REVIEWED}

\begin{tabular}{|c|c|c|c|c|c|}
\hline $\begin{array}{l}\text { PUBLICATION } \\
\text { DETAILS }\end{array}$ & AIM & $\begin{array}{l}\text { SETTING AND } \\
\text { LOCATION }\end{array}$ & $\begin{array}{l}\text { STUDY DESIGN AND } \\
\text { METHODOLOGY }\end{array}$ & $\begin{array}{l}\text { SAMPLE SIZE AND } \\
\text { CHARACTERISTICS }\end{array}$ & STUDY FINDINGS \\
\hline $\begin{array}{l}\text { Aarons et al., } \\
2015 \text { [19] }\end{array}$ & $\begin{array}{l}\text { The main aim of this study } \\
\text { was to assess the } \\
\text { feasibility, acceptability } \\
\text { and perceived utility of } \\
\text { leadership and } \\
\text { organisation change } \\
\text { implementation (LOCl). } \\
\text { The study also assessed } \\
\text { preliminary effects of LOCl } \\
\text { on supervisee-rated } \\
\text { leader readiness and } \\
\text { support behaviours. }\end{array}$ & $\begin{array}{l}\text { Three different } \\
\text { agencies that } \\
\text { provide mental } \\
\text { health services } \\
\text { to children and } \\
\text { families in } \\
\text { California, } \\
\text { United States of } \\
\text { America }\end{array}$ & $\begin{array}{l}\text { Mixed method two- } \\
\text { arm randomised } \\
\text { pilot study in which } \\
\text { leaders were } \\
\text { assigned to LOCl or } \\
\text { to a webinar } \\
\text { control condition }\end{array}$ & $\begin{array}{l}12 \text { mental health service } \\
\text { team leaders } \\
100 \text { staff that reported to } \\
\text { the leaders }\end{array}$ & $\begin{array}{l}\text { Quantitative and qualitative findings } \\
\text { support the LOCI training and organisational } \\
\text { strategy interventions in regard to feasibility, } \\
\text { acceptability and perceived utility, as well } \\
\text { as impact on leader and supervisee-rated } \\
\text { outcomes. } \\
\text { The results suggest that LOCI may be a } \\
\text { viable strategy to support organisations in } \\
\text { preparing for implementation and } \\
\text { sustainability of Evidence Based Practice. }\end{array}$ \\
\hline $\begin{array}{l}\text { Ang et al., } \\
2016 \text { [35] }\end{array}$ & $\begin{array}{l}\text { To develop and explore } \\
\text { the psychometric } \\
\text { properties of the Aspiring } \\
\text { leaders in Healthcare - } \\
\text { Empowering individuals } \\
\text { (AHEAD) competency } \\
\text { instrument developed by } \\
\text { the authors for existing } \\
\text { and emerging allied } \\
\text { health practitioners. }\end{array}$ & $\begin{array}{l}\text { Allied Health } \\
\text { Division of the } \\
\text { Singapore } \\
\text { General Hospital }\end{array}$ & $\begin{array}{l}\text { A cross-sectional } \\
\text { survey design }\end{array}$ & $\begin{array}{l}106 \text { allied health } \\
\text { practitioners ( } 34 \text { men } \\
\text { and } 72 \text { women) of } \\
\text { different professional } \\
\text { grades and professions }\end{array}$ & $\begin{array}{l}\text { Internal consistency of AHEAD was excellent } \\
\text { (q-values >0.88). Total and component } \\
\text { AHEAD and Leadership Practices Inventory } \\
\text { (LPI) scores correlated moderately } \\
\text { (Spearman P values, } 0.37 \text { to } 0.58 \text { ). The c- } \\
\text { index for discriminating between allied } \\
\text { health practitioners' grades was higher for } \\
\text { AHEAD than for the LPI ( } 0.76 \text { vs. } 0.65 \text { ). The } \\
\text { results provide initial evidence for the use of } \\
\text { AHEAD to assess leadership competency in } \\
\text { allied health practitioners. }\end{array}$ \\
\hline $\begin{array}{l}\text { Bradd et al., } \\
2017 \text { [1] }\end{array}$ & $\begin{array}{l}\text { To investigate the opinions } \\
\text { and perceptions of allied } \\
\text { health directors / advisors }\end{array}$ & $\begin{array}{l}\text { New South } \\
\text { Wales (NSW) } \\
\text { Health, allied }\end{array}$ & $\begin{array}{l}\text { Study completed } \\
\text { over 6-months and } \\
\text { consisted of two }\end{array}$ & $\begin{array}{l}15(88 \%) \text { allied health } \\
\text { directors or advisors }\end{array}$ & $\begin{array}{l}\text { Participants indicated the need to build and } \\
\text { grow their influence to more clearly } \\
\text { demonstrate allied health's contribution and }\end{array}$ \\
\hline
\end{tabular}

Enablers for allied health front-line managers in public health environments to deliver sustainable patient care Asia Pacific Journal of Health Management 2020; 15(4):i337. doi: 10.24083/apjhm.v15i4.337 


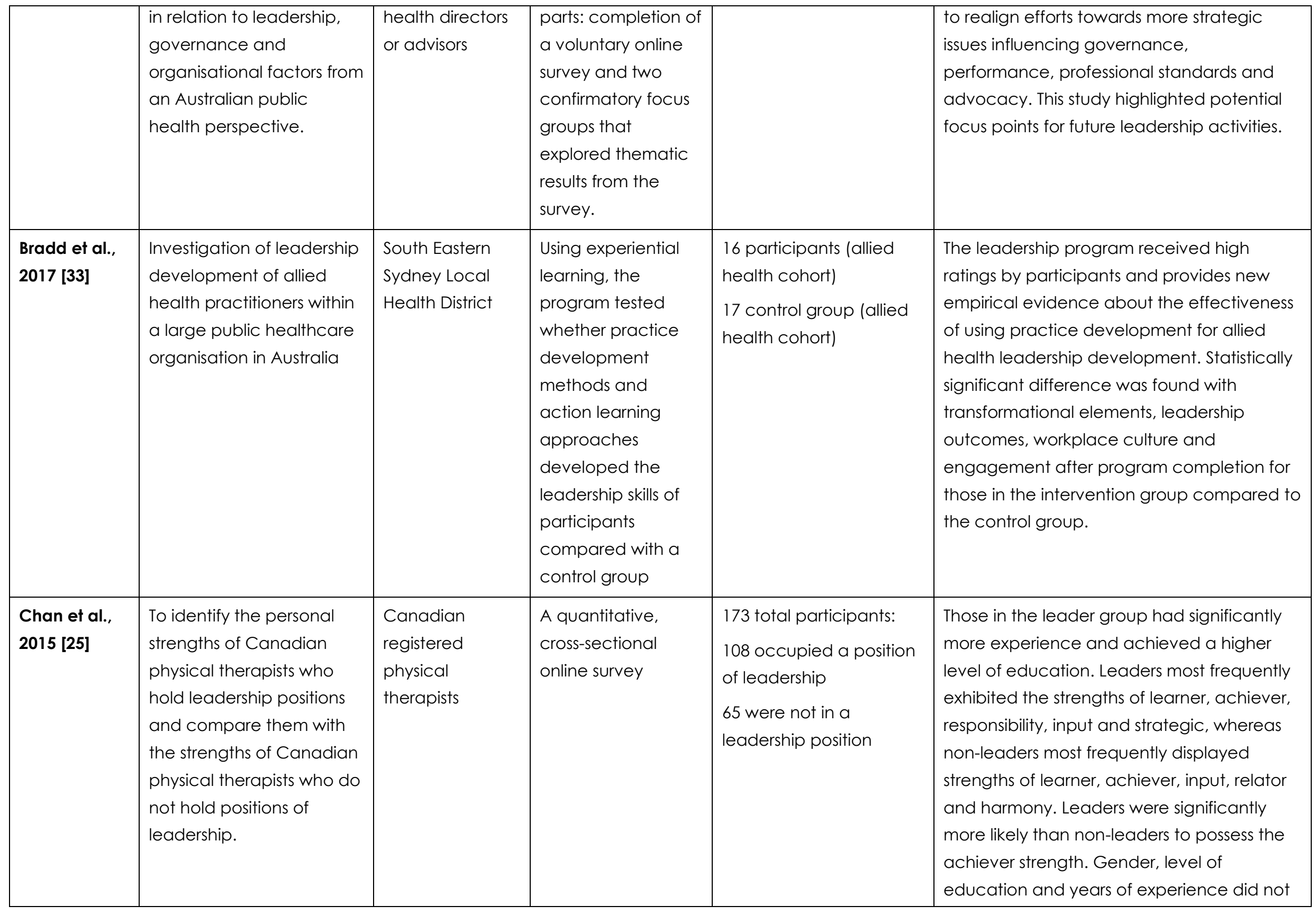




\begin{tabular}{|c|c|c|c|c|c|}
\hline & & & & & $\begin{array}{l}\text { significantly influence which strengths were } \\
\text { present in the leadership profile. } \\
\text { There is substantial overlap between leaders } \\
\text { and non-leaders in terms of leadership } \\
\text { profile. }\end{array}$ \\
\hline $\begin{array}{l}\text { Desveaux et } \\
\text { al., } 2016 \text { [26] }\end{array}$ & $\begin{array}{l}\text { To explore the } \\
\text { characteristics of physical } \\
\text { therapy leaders in } \\
\text { academic and } \\
\text { managerial roles. }\end{array}$ & $\begin{array}{l}\text { Canadian } \\
\text { Physiotherapy } \\
\text { Association }\end{array}$ & $\begin{array}{l}\text { A quantitative, } \\
\text { cross-sectional } \\
\text { nationwide study } \\
\text { using an online } \\
\text { questionnaire } \\
\text { distributed via email } \\
\text { Those who met } \\
\text { criteria also } \\
\text { completed the } \\
\text { Clifton } \\
\text { StrengthsFinder } \\
\text { survey }\end{array}$ & $\begin{array}{l}88 \text { participants }(52 \\
\text { managers, } 36 \\
\text { academics) }\end{array}$ & $\begin{array}{l}\text { The most prevalent strengths among both } \\
\text { academics and managers were the learner } \\
\text { and achiever characteristics. } \\
\text { The study concluded that academics and } \\
\text { managers in physical therapy share similar } \\
\text { core characteristics, with slight variations in } \\
\text { secondary characteristics. }\end{array}$ \\
\hline $\begin{array}{l}\text { Desveaux et } \\
\text { al., } 2012 \text { [34] }\end{array}$ & $\begin{array}{l}\text { To explore the concept of } \\
\text { leadership from the } \\
\text { perspective of physical } \\
\text { therapists in Canada. }\end{array}$ & $\begin{array}{l}\text { Canadian } \\
\text { Physiotherapy } \\
\text { Association - }\end{array}$ & $\begin{array}{l}\text { A quantitative, } \\
\text { cross-sectional } \\
\text { nationwide study }\end{array}$ & $\begin{array}{l}1,875 \text { responded }(30 \%) \\
\text { of } 6,156 . \\
1,511(80.6 \%) \text { completed } \\
\text { the questionnaire }\end{array}$ & $\begin{array}{l}\text { The top three characteristics of } \\
\text { communication, professionalism and } \\
\text { credibility that physical therapists perceive }\end{array}$ \\
\hline
\end{tabular}

Enablers for allied health front-line managers in public health environments to deliver sustainable patient care Asia Pacific Journal of Health Management 2020; 15(4):i337. doi: 10.24083/apjhm.v15i4.337 


\begin{tabular}{|c|c|c|c|c|c|}
\hline & & $\begin{array}{l}\text { registered email } \\
\text { address }\end{array}$ & $\begin{array}{l}\text { using web-based } \\
\text { survey }\end{array}$ & & $\begin{array}{l}\text { as important differ from those reported } \\
\text { among other health professions. } \\
\text { Practising in the private sector contributed } \\
\text { significantly to the perceived importance of } \\
\text { business acumen ( } p<0,001) \text {. Of the } 79.6 \% \text { of } \\
\text { respondents who self-declared as leaders, } \\
\text { male gender, primary work facility in private } \\
\text { practice or educational institution and } \\
\text { supervision of students were factors } \\
\text { associated with self-declaration as a leader. }\end{array}$ \\
\hline $\begin{array}{l}\text { Firestone D, } \\
2009 \text { [23] }\end{array}$ & $\begin{array}{l}\text { To investigate leadership } \\
\text { behaviours among } \\
\text { chairpersons in allied } \\
\text { health programs, based } \\
\text { on their perceptions and } \\
\text { the perceptions of the } \\
\text { faculty }\end{array}$ & $\begin{array}{l}\text { The chairpersons } \\
\text { were invited to } \\
\text { participant via } \\
\text { email and were } \\
\text { located in the } \\
\text { northeast of the } \\
\text { United States }\end{array}$ & $\begin{array}{l}\text { A quantitative study } \\
\text { utilising the } \\
\text { Multifactorial } \\
\text { Leadership } \\
\text { Questionnaire (MLQ } \\
\text { Form 5X-Short) and } \\
\text { a supplemental } \\
\text { questionnaire of } \\
\text { demographic and } \\
\text { program } \\
\text { information }\end{array}$ & $\begin{array}{l}138 \text { chairpersons and } \\
327 \text { faculty responded to } \\
\text { the survey requesting } \\
\text { demographic, program } \\
\text { information and } \\
\text { completion of the MLQ }\end{array}$ & $\begin{array}{l}\text { Findings support the view that chairpersons } \\
\text { predominately demonstrate leadership } \\
\text { behaviors associated with transformational } \\
\text { leadership factors and the contingent } \\
\text { reward factor of transactional leadership. } \\
\text { This study concluded that further } \\
\text { development of the transformational } \\
\text { leadership behaviours of chairpersons } \\
\text { should be a priority for allied health } \\
\text { professions. }\end{array}$ \\
\hline $\begin{array}{l}\text { Fleming- } \\
\text { Castaldy \& } \\
\text { Patro, } 2012 \\
\text { [14] }\end{array}$ & $\begin{array}{l}\text { To examine the leadership } \\
\text { characteristics of } \\
\text { occupational therapy } \\
\text { clinical managers in the } \\
\text { field using the leadership } \\
\text { practices inventory }\end{array}$ & $\begin{array}{l}\text { Occupational } \\
\text { Therapy } \\
\text { managers in the } \\
\text { United States } \\
\text { who were } \\
\text { members of the } \\
\text { American } \\
\text { Occupational } \\
\text { Therapy } \\
\text { Associations } \\
\text { administration }\end{array}$ & $\begin{array}{l}\text { A non-experimental } \\
\text { survey design } \\
\text { utilising a } \\
\text { demographic } \\
\text { measure and the } \\
\text { Leadership } \\
\text { Practices Inventory } \\
\text { (LPI) }\end{array}$ & $\begin{array}{l}66(44 \%) \text { surveys were } \\
\text { completed, with } 53 \\
(33 \%) \text { meeting the } \\
\text { criteria for analysis }\end{array}$ & $\begin{array}{l}\text { No significant associations were found } \\
\text { between respondent demographics and LPI } \\
\text { scores. Respondents reported leadership } \\
\text { capabilities reflect their power to influence } \\
\text { and lead the profession in a demanding } \\
\text { and ever-changing healthcare } \\
\text { environment. }\end{array}$ \\
\hline
\end{tabular}




\begin{tabular}{|c|c|c|c|c|c|}
\hline & & $\begin{array}{l}\text { and } \\
\text { management } \\
\text { special interest } \\
\text { section }\end{array}$ & & & \\
\hline $\begin{array}{l}\text { Guerrero et } \\
\text { al, } 2016 \text { [18] }\end{array}$ & $\begin{array}{l}\text { To identify strategies that } \\
\text { addiction treatment } \\
\text { program leaders report } \\
\text { using to implement new } \\
\text { practices }\end{array}$ & $\begin{array}{l}\text { Los Angeles } \\
\text { County in the } \\
\text { USA }\end{array}$ & $\begin{array}{l}\text { Stage and iterative } \\
\text { mixed-methods } \\
\text { approach utilising } \\
\text { focus groups and } \\
\text { semi-structured } \\
\text { interviews }\end{array}$ & $\begin{array}{l}122 \text { substance use } \\
\text { disorder programs (SUD). } \\
\text { Participants completed } \\
\text { a questionnaire } 2 \text { weeks } \\
\text { before the study started. } \\
\text { Each participant took } \\
\text { part in two-hour focus } \\
\text { groups ( } 2 \text { for clinical } \\
\text { supervisors, } 2 \text { for } \\
\text { program directors) }\end{array}$ & $\begin{array}{l}\text { The study identified implicit leadership } \\
\text { strategies that managers in SUD programs } \\
\text { use to implement evidence-based } \\
\text { programs (EBPs) in their organisations. The } \\
\text { study also linked these strategies to two } \\
\text { leadership styles of transformational and } \\
\text { transactional leadership. The leadership } \\
\text { approach to EBPs implementation was } \\
\text { knowledgeable, proactive, supportive and } \\
\text { perseverant. }\end{array}$ \\
\hline $\begin{array}{l}\text { Kutz M, } 2009 \\
\text { [16] }\end{array}$ & $\begin{array}{l}\text { To explore leadership in } \\
\text { athletic training and the } \\
\text { implications for practice } \\
\text { and education in allied } \\
\text { health care }\end{array}$ & $\begin{array}{l}\text { United states, } \\
\text { through the } \\
\text { National Athletic } \\
\text { Trainers } \\
\text { Association } \\
\text { national office }\end{array}$ & $\begin{array}{l}\text { Non-experimental, } \\
\text { exploratory } \\
\text { research design: a } \\
\text { Delphi technique } \\
\text { and a national } \\
\text { survey }\end{array}$ & $\begin{array}{l}\text { Phase 1: expert panellists } \\
\text { (18) evaluated } 39 \\
\text { leadership } \\
\text { competencies derived } \\
\text { from an extensive } \\
\text { literature review of } 220 \\
\text { peer-reviewed journals } \\
\text { and textbooks to }\end{array}$ & $\begin{array}{l}\text { The study found that } 49 \text { leadership } \\
\text { competencies were rated important for } \\
\text { practice and } 48 \text { for education. Exploratory } \\
\text { factor analysis revealed that leadership } \\
\text { competencies were organised by four } \\
\text { constructs: 1) personality characteristics, 2) } \\
\text { diagnosing context and people skills, 3) } \\
\text { communication and initiative and 4) }\end{array}$ \\
\hline
\end{tabular}




\begin{tabular}{|c|c|c|c|c|c|}
\hline & & & & $\begin{array}{l}\text { develop the Leadership } \\
\text { Development in Athletic } \\
\text { training (LDAT) } \\
\text { instrument } \\
\text { Phase 2: implemented } \\
\text { the LDAT instrument via a } \\
\text { web-based survey to } 161 \\
\text { respondents (random } \\
\text { selection) }\end{array}$ & $\begin{array}{l}\text { strategic thinking. Each leadership construct } \\
\text { significantly increased in importance as the } \\
\text { level of the Athletic training education } \\
\text { program progressed. }\end{array}$ \\
\hline $\begin{array}{l}\text { McGowan \& } \\
\text { Stokes, } 2017 \\
{[5]}\end{array}$ & $\begin{array}{l}\text { To investigate the } \\
\text { perceptions of } \\
\text { physiotherapists in Ireland } \\
\text { of leadership and } \\
\text { leadership characteristics } \\
\text { and to explore their } \\
\text { participation in leadership } \\
\text { development training }\end{array}$ & $\begin{array}{l}\text { Ireland, } \\
\text { members of the } \\
\text { Irish Society of } \\
\text { Chartered } \\
\text { Physiotherapists }\end{array}$ & $\begin{array}{l}\text { Cross-sectional } \\
\text { nationwide study } \\
\text { via an internet- } \\
\text { based survey } \\
\text { administered via } \\
\text { email }\end{array}$ & $\begin{array}{l}N=2,787 \text { surveys sent out } \\
\text { via email with } 615 \\
\text { responses to the survey }\end{array}$ & $\begin{array}{l}\text { A high proportion of respondents ( } 74 \%) \\
\text { perceived themselves to be a leader, } \\
\text { factors associated with this perception were } \\
\text { time since graduation, highest qualification } \\
\text { attained and leadership training. Leadership } \\
\text { training was also associated with placing } \\
\text { greater importance on achieving a } \\
\text { leadership position. } 41.5 \% \text { of respondents } \\
\text { had completed some sort of leadership } \\
\text { training. Communication and } \\
\text { professionalism were the most highly rated } \\
\text { leadership characteristics in all } 3 \text { settings. }\end{array}$ \\
\hline $\begin{array}{l}\text { McGowan et } \\
\text { al., } 2016 \text { [6] }\end{array}$ & $\begin{array}{l}\text { To contribute to the } \\
\text { growing body of research } \\
\text { on leadership in } \\
\text { physiotherapy by } \\
\text { comparing leadership- } \\
\text { related perceptions of } \\
\text { physiotherapists in Ireland } \\
\text { and Canada }\end{array}$ & $\begin{array}{l}\text { Physiotherapists } \\
\text { in Ireland and } \\
\text { Canada }\end{array}$ & $\begin{array}{l}\text { Comparison of the } \\
\text { results of a survey of } \\
\text { Canadian } \\
\text { physiotherapists } \\
\text { with those of the } \\
\text { same survey } \\
\text { administered to Irish } \\
\text { physiotherapists }\end{array}$ & $\begin{array}{l}\text { 2-portion Z-tests to } \\
\text { compare the } \\
\text { percentage of } \\
\text { physiotherapists in } \\
\text { Ireland who self- } \\
\text { declared as a leader } \\
\text { with the percentage of } \\
\text { physiotherapists in } \\
\text { Canada that declared } \\
\text { the same }\end{array}$ & $\begin{array}{l}\text { Physiotherapists in both Canada and Ireland } \\
\text { most often rated communication and } \\
\text { professionalism as extremely important } \\
\text { characteristics. Physiotherapists in Canada } \\
\text { were more likely than those in Ireland to } \\
\text { perceive themselves as leaders. }\end{array}$ \\
\hline
\end{tabular}

Enablers for allied health front-line managers in public health environments to deliver sustainable patient care Asia Pacific Journal of Health Management 2020; 15(4):i337. doi: 10.24083/apjhm.v15i4.337 


\begin{tabular}{|c|c|c|c|c|c|}
\hline $\begin{array}{l}\text { McGowan et } \\
\text { al., } 2016 \text { [30] }\end{array}$ & $\begin{array}{l}\text { To investigate the } \\
\text { leadership frames of } \\
\text { Physiotherapy managers } \\
\text { in Ireland }\end{array}$ & $\begin{array}{l}\text { Ireland, the } \\
\text { chartered } \\
\text { Physiotherapists } \\
\text { in Management } \\
\text { employment } \\
\text { group of the Irish } \\
\text { Society of } \\
\text { Chartered } \\
\text { Physiotherapists }\end{array}$ & $\begin{array}{l}\text { An internet-based } \\
\text { survey administered } \\
\text { via email to a } \\
\text { purposive sample }\end{array}$ & $\begin{array}{l}N=73 \text { Physiotherapists } \\
\text { were sent the survey with } \\
45(62 \%) \text { respondents. }\end{array}$ & $\begin{array}{l}\text { The human resource frame was the most } \\
\text { frequently used (61\%) and the political } \\
\text { frame was the least (9\%). The majority of } \\
\text { respondents reported using one or no } \\
\text { frames at all (65\%). There was a statistically } \\
\text { significant trend between the number of } \\
\text { leadership frames a physiotherapy manager } \\
\text { used and their effectiveness as a manager } \\
\text { and leader. They concluded that the } \\
\text { development of physiotherapy managers } \\
\text { underused skills through appropriate } \\
\text { leadership development training may } \\
\text { enhance their leadership skill set and make } \\
\text { them more confident leaders. }\end{array}$ \\
\hline $\begin{array}{l}\text { Mickan et al, } \\
2018 \text { [9] }\end{array}$ & $\begin{array}{l}\text { To identify key } \\
\text { organisational contexts } \\
\text { and corresponding } \\
\text { mechanisms that } \\
\text { influenced effective } \\
\text { outcomes for allied health } \\
\text { professionals }\end{array}$ & $\begin{array}{l}\text { Nine } \\
\text { Queensland } \\
\text { Health services }\end{array}$ & $\begin{array}{l}\text { A quantitative } \\
\text { realist evaluation } \\
\text { including 1-1 } \\
\text { interviews and } \\
\text { focus groups }\end{array}$ & $\begin{array}{l}5 \text { executives } \\
49 \text { allied health } \\
\text { professionals }\end{array}$ & $\begin{array}{l}\text { Executive allied health leadership roles } \\
\text { enable allied health leaders to use their } \\
\text { influence in organisational planning and } \\
\text { decision-making to ensure allied health } \\
\text { professionals deliver successful patient care } \\
\text { services. Professional governance systems } \\
\text { embed the management and support of } \\
\text { the clinical most efficiently within } \\
\text { professional disciplines. With consistent data } \\
\text { management systems, allied health } \\
\text { professional staff can be integrated within } \\
\text { clinical teams that provide high-quality } \\
\text { care. Interprofessional learning opportunities } \\
\text { can enhance collaborative teamwork. } \\
\text { Allied health professionals who are } \\
\text { supported to understand and use research } \\
\text { can deliver positive patient and business } \\
\text { outcomes for the health service. }\end{array}$ \\
\hline
\end{tabular}




\begin{tabular}{|c|c|c|c|c|c|}
\hline $\begin{array}{l}\text { Petchy et al, } \\
2013 \text { [31] }\end{array}$ & $\begin{array}{l}\text { To investigate the lived } \\
\text { experience of allied } \\
\text { health practitioners and } \\
\text { how these vary by } \\
\text { management level and } \\
\text { the factors they perceive } \\
\text { as promoting or restraining } \\
\text { their engagement in } \\
\text { management and their } \\
\text { career progression }\end{array}$ & $\begin{array}{l}\text { England } \\
\text { National Health } \\
\text { Service (NHS): } \\
\text { four sites at } \\
\text { Naguard and } \\
\text { Whiteford NHS } \\
\text { trusts, Greenshire } \\
\text { Community } \\
\text { Health and } \\
\text { Cloffaugh } \\
\text { Mental Health } \\
\text { Care }\end{array}$ & $\begin{array}{l}\text { Case studies: } \\
\text { multiple methods of } \\
\text { observations, } \\
\text { informal } \\
\text { conversations, } \\
\text { formal interviews }\end{array}$ & $\begin{array}{l}4 \mathrm{NHS} \text { sites with clinician } \\
\text { managers }\end{array}$ & $\begin{array}{l}\text { Six broad and intersecting themes emerged } \\
\text { from the case studies: 1) the problematic } \\
\text { nature of clinician manager identity, 2) the } \\
\text { variability of clinician management in } \\
\text { relation to multiple styles of clinician } \\
\text { management, rather than a single style, 3) } \\
\text { the variable and complex relationship } \\
\text { between the managerial and the clinical on } \\
\text { the front line, 4) clinician management as a } \\
\text { problem to be managed, 5) the } \\
\text { significance of emotional labour in clinician } \\
\text { management, 6) the problematic transition } \\
\text { from clinician management to clinical } \\
\text { leadership. } \\
\text { There appears to be an association } \\
\text { between management/ leadership style } \\
\text { and their gender and professional values } \\
\text { among the clinician managers studied. }\end{array}$ \\
\hline $\begin{array}{l}\text { Schafer D, } \\
2002[27]\end{array}$ & $\begin{array}{l}\text { To investigate the } \\
\text { perceived importance of } \\
\text { managerial role and skill } \\
\text { categories among three } \\
\text { groups of physical } \\
\text { therapists }\end{array}$ & $\begin{array}{l}\text { United States } \\
\text { (US) }\end{array}$ & $\begin{array}{l}\text { Survey across three } \\
\text { distinct groups }\end{array}$ & $\begin{array}{l}\text { Three groups: } 1 \text { ) Faculty } \\
\text { members in professional } \\
\text { physical therapist } \\
\text { education programs } \\
(\mathrm{N}=155) \text {. 2) Physical } \\
\text { Therapists who held } \\
\text { management positions } \\
\text { in US hospitals ( } \mathrm{N}=300 \text { ) } 3 \text { ) } \\
\text { Physical Therapists who } \\
\text { held management } \\
\text { positions in private } \\
\text { practices in the US. } \\
\text { Total respondents } \\
(\mathrm{n}=343 \text { ) }\end{array}$ & $\begin{array}{l}\text { All groups identified communication, } \\
\text { financial control, entrepreneur, resource } \\
\text { allocator and leader as the } 5 \text { most } \\
\text { important categories and rated technical } \\
\text { expert and figurehead as least important. } \\
\text { Work settings appears to have an impact on } \\
\text { level of importance placed on managerial } \\
\text { work categories. Those with universal } \\
\text { application were communication, financial } \\
\text { control and resource allocator. }\end{array}$ \\
\hline
\end{tabular}




\begin{tabular}{|c|c|c|c|c|c|}
\hline $\begin{array}{l}\text { Snodgrass et } \\
\text { al, } 2008 \text { [3] }\end{array}$ & $\begin{array}{l}\text { A pilot study to investigate } \\
\text { the association between } \\
\text { occupational therapy } \\
\text { practitioners' perceptions } \\
\text { of rehabilitation managers } \\
\text { leadership styles and the } \\
\text { outcomes of leadership }\end{array}$ & Tennessee, US & $\begin{array}{l}\text { Cross-sectional, } \\
\text { direct data survey } \\
\text { research design }\end{array}$ & $\begin{array}{l}\text { A random sample of } 500 \\
\text { survey participants from } \\
\text { a mailing list of OT } \\
\text { practitioners from the } \\
\text { Tennessee Occupational } \\
\text { Therapy Association. } \\
\text { Respondents included = } \\
73 \text { OT practitioners. }\end{array}$ & $\begin{array}{l}\text { The results suggest that transformational } \\
\text { leadership styles have a positive association } \\
\text { with leadership outcomes, whereas } \\
\text { transactional leadership styles have a } \\
\text { negative association, excluding the positive } \\
\text { transactional contingent reward attribute. }\end{array}$ \\
\hline $\begin{array}{l}\text { Stagnitti et } \\
\text { al., } 2005 \text { [4] }\end{array}$ & $\begin{array}{l}\text { To explore issues relating } \\
\text { to recruitment and } \\
\text { retention }\end{array}$ & $\begin{array}{l}\text { South West } \\
\text { Victoria, } \\
\text { Australia }\end{array}$ & Survey & $\begin{array}{l}\mathrm{N}=491 \text { surveys sent to } \\
\text { allied health } \\
\text { professionals in the South } \\
\text { West region of Victoria. } \\
\mathrm{N}=184 \text { professionals } \\
\text { returned the survey, } \\
\mathrm{N}=138 \text { met the criteria as } \\
\text { an allied health } \\
\text { professional. }\end{array}$ & $\begin{array}{l}\text { Results were related to Maslow's hierarchy } \\
\text { of needs, with professional needs identified } \\
\text { as feeling supported, orientation to the } \\
\text { position, clear role description and that they } \\
\text { would recommend the position to others. } \\
\text { The immediate management structure was } \\
\text { significantly related to retention. Reasons for } \\
\text { leaving were related to management } \\
\text { categories e.g. management structures, } \\
\text { lack of career structure and lack of } \\
\text { professional support. Reasons for not } \\
\text { recommending their current position were: } \\
\text { not for long term career, risk of deskilling if } \\
\text { staying too long and financially } \\
\text { unrewarding. Positive reasons for staying } \\
\text { related to management: flexible work } \\
\text { conditions, variety of clinical and } \\
\text { management experience, good working } \\
\text { environment, good support and autonomy. }\end{array}$ \\
\hline $\begin{array}{l}\text { Wylie et al., } \\
2007 \text { [7] }\end{array}$ & $\begin{array}{l}\text { To explore self-reported } \\
\text { transformational } \\
\text { leadership behaviour } \\
\text { profiles within the six } \\
\text { largest allied health }\end{array}$ & $\begin{array}{l}\text { National Health } \\
\text { Service in } \\
\text { Scotland, } \\
\text { including } 4 \\
\text { health boards }\end{array}$ & $\begin{array}{l}\text { Questionnaire } \\
\text { posted to } 1700 \\
\text { allied health groups } \\
\text { from } 6 \text { of the largest } \\
\text { professions. A }\end{array}$ & $\begin{array}{l}N=753 \text { allied health } \\
\text { professionals were } \\
\text { administered the shorter } \\
\text { version of the MLQ and }\end{array}$ & $\begin{array}{l}\text { The study identified significant differences in } \\
\text { transformational leadership behaviours } \\
\text { between individual allied health professions. } \\
\text { Radiographers and podiatrists scored } \\
\text { consistently lower than the other }\end{array}$ \\
\hline
\end{tabular}




\begin{tabular}{|l|l|l|l|l|}
\hline & $\begin{array}{l}\text { profession groups in the } \\
\text { NHS in Scotland }\end{array}$ & $\begin{array}{l}\text { selective } \\
\text { convenience } \\
\text { sampling technique } \\
\text { was utilised. A } \\
\text { modified cluster } \\
\text { sampling technique } \\
\text { was used for } \\
\text { randomisation }\end{array}$ & $\begin{array}{l}\text { a contextual } \\
\text { demographic survey. }\end{array}$ & $\begin{array}{l}\text { professional groups across the range of } \\
\text { transformational behaviours. The higher the } \\
\text { seniority and prior leadership training } \\
\text { positively influenced transformational } \\
\text { behaviour. Employment within a primary or } \\
\text { secondary setting or a multidisciplinary or } \\
\text { unidisciplinary team had no effect. }\end{array}$ \\
\hline
\end{tabular}

